\title{
REVIEW OF BULAT KHAMIDULLIN'S BOOK “... THE CURSED DAUGHTER OF THE GOLDEN HORDE ...”: ESSAYS AND HISTORIOGRAPHIC NOTES ON THE HISTORY OF THE GOLDEN HORDE AND THE KAZAN KHANATE: A MONOGRAPH. - KAZAN: TATAR PUBLISHING HOUSE, 2018. - 295 p.
}

\author{
Iskander Ayazovich Gilyazov, \\ Institute of Tatar Encyclopedia and Regional Studies, \\ Academy of Sciences of the Republic of Tatarstan, \\ 56 Puskin Str., Kazan, 420111, Russian Federation, \\ gilyazov1958@mail.ru.
}

\begin{abstract}
This article reviews B. L. Khamidullin's monograph devoted to the history of the Golden Horde and the Kazan khanate. The article reveals the scientific novelty of this research, its structure is briefly characterized, and the relevance of this work is specified.
\end{abstract}

Key words: Golden Horde, Kazan khanate, history, historiography.

The centuries-old history of Russia is made up of the histories of peoples inhabiting it. The Russian multinational state did not emerge from scratch, its formation was preceded by the history of many state-political formations, among them are the Golden Horde and the Kazan Khanate. It is not accidental that, in 2019, the scientific community of the Russian Federation celebrates the 750th anniversary of the Golden Horde. Of great importance is the study of the great all-Turkic and, in particular, the Tatar heritage, and its contribution to the formation of the all-Russian statehood.

Tatar people occupy a place of their own in the history of Russia both in number (they come second after the number of Russian people), the territory of settlement, and in terms of their contribution to the development of statehood, culture, and economy of our common great country. Among the key stages in the ethnogenesis and development of Tatar people, their political structure, and the formation of national culture are the Golden Horde and the post-Horde Tatar khanates. The history of the Golden Horde and the post-Horde Tatar Khanate is a significant part of the history of a number of Russia peoples: the Bashkir, the Crimean Tatar, the Mari, the Mordovian, the Nogai, the Russian, the Udmurt, the Ukrainian, the Chuvash and many others. Rightfully, the outstanding Russian historian S. Soloviev considered the fact of the Kazan Khanate's joining Russia in the middle of the 16th century to be the most important event in Russian history, which in many respects determined its further course of development.

However, until now, the Kazan Khanate, often due to inertia caused by Russian chronicles and pre-revolutionary historiography, was considered exclusively as an "enemy" ("the cursed daughter of the Golden Horde") of the Russian state. Moreover, for Russian scholars, including Tatarstan researchers, the Kazan Khanate is still clearly inferior in interest to the Golden Horde or to the Turkic empires of the early Middle Ages, it remains in their "thick shadow". Therefore, the topic, addressed by Bulat Khamidullin in his new book, is certainly more than relevant for the history of Russia.

It is no exaggeration to say that Bulat Khamidullin is one of the few experts in the Kazan Khanate not only in Tatarstan, but also in Russia. For more than 25 years, he has been studying the ethnosocial and ethno-political history of the medieval Turks and the Tatar Kazan state. In 2002, his monograph "The Peoples of the Kazan Khanate" was released, which was the first work in nearly 80 years after Mikhail Khudyakov's "Essays on the History of the Kazan Khanate", a book published in 1923 and specifically devoted to this state. Subsequently, he wrote and published five more books and about 100 research and popular science articles on this topic. He is the author of the articles devoted to the Kazan Khanate, written for the Great Russian Encyclopedia and the section on the Kazan Khanate in the fourth volume of the fundamental seven-volume "The History of the Tatars since Ancient Times", which is the evidence of his recognized authority in this field. The book is wellwritten, it has an excellent academic and literary language, for the author is a brilliant publicist and translator, a member of the Writers' Union of the Republic of Tatarstan, thus, reading this book is a 
pleasure. It is accessible for different categories of readers: both academic researchers and those just interested in history.

Structurally, the book consists of three parts, combining nineteen articles, essays, as well as a separate appendix - a list of the author's publications on the history of the Kazan Khanate.

The story about the Kazan Khanate itself is preceded by a section on the era of the Golden Horde. It includes two large essays, which scrupulously examine all key points of its history as well as many controversial issues, including the process of the Golden Horde Tatars' ethnic consolidation. Besides, the unique world of the Golden Horde Era is comprehensively shown based on the civilizational approach. To this end, Bulat Khamidullin attracts the widest possible range of sources from Russian and foreign historiography. I would like to emphasize that the author rightly considers the Golden Horde period to be an integral part of the history of Russia, not only as the history of its Turkic peoples, but also of the country as a whole, and the history of many states and peoples of Eurasia. According to Khamidullin, the significance of its enormous legacy is the fact that the Golden Horde became the "cradle" for many ethnic groups that now make up a large part of Russia's population and its adjacent territories: the Tatars, the Bashkirs, the Nogai, the Kumyks, the Uzbeks, the Kazakhs, the Cossacks and others. It was the Golden Horde that for a long time first gathered Turkic, Mongolian, Finno-Ugric, East Slavic, Siberian, Caucasian and other peoples of Eurasia in a single political and economic space, which later became a part of Russia, thereby giving them the first experience of living together, bringing closer their cultures, lifestyles, and mentality.

Directly and indirectly, the development of Russian statehood was strongly influenced by the Golden Horde. Muscovite Russia, developing as a part of the Golden Horde, learned from its experience how to unite lands and peoples in the expanses of Eurasia. Russia preserved many of the Horde's useful traditions in the system of governance, economy, and culture. The experience, gained during the period of mutual coexistence with the Golden Horde, eventually enabled RusRussia to become the largest state in the world. All this allows the author to speak about the historical continuity of the great Eurasian superpowers - the Golden Horde, Muscovy, the Russian Empire, the USSR, and the Russian Federation, consistently passing on to each other the mission of "gathering" peoples within common borders.
The second part of the book, consisting of four essays, is devoted to the rich history and, in particular, to the ethno-political situation in the Kazan Khanate. The author shows, based on the widest possible range of currently known sources and published research works, the Khanate as a large and economically developed state, a structureforming element of the region and the whole of Central Eurasia. The same as in the previous works, the author consistently defends his point of view and convincingly shows that the Kazan Khanate was a national state not only for the Tatars, but also for other Volga and Ural peoples, who recognized it as their Homeland, seeing the positive outcomes of belonging to a single sociopolitical and ethnocultural space. The author manages to build a coherent conceptual scheme of the ethnopolitical situation, which presents the Kazan Khanate as an integral ethnosocial community of all Turkic and Finno-Ugric peoples, inhabiting it (thoroughly exemplified by southern Udmurts), and as a "star" of a unified "constellation" of the Turkic-Tatar states, which emerged after the collapse of the Golden Horde on the basis of "the unified ruling clan of Chingizids-Juchids, the unity of its state-forming people with a common language, a common religion, and culture".

The third part constitutes the bulk of the book, it has fourteen essays on both the entire Russian (Russian pre-revolutionary, Soviet, post-Soviet) and the national Tatar historiography of the Kazan Khanate. They trace its formation and development from the chronicles of the 15 th -16 th centuries to the works of Tatar historians in the early 21 st century. The essays thoroughly analyze the views of the founders and principal researchers of this area of history as well as conceptual approaches of historians and their contribution to the study of the Kazan Khanate history. From these essays, the reader can gain information about a large stratum of pre-revolutionary Russian historiography, including relevant plots from the works of the Russian historiography classics by N. M. Karamzin, S. M. Soloviev, V. O. Klyuchevsky, N. I. Kostomarov, field-specific works by P. I. Rychkov, K. F. Fuchs, N. K. Bazhenov, V. V. Veliyaminova-Zernov, G. I. Peretyatkovich, S. M. Shpilevsky, and the views on the history of the Kazan Khanate of Tatar pre-revolutionary intellectuals. The author presents a relatively scanty Soviet historiography, including the works by $\mathrm{H}$. G. Gimadi and Sh. F. Mukhamedyarov, which, until recently, were little-known to the general public. A separate essay is devoted to a much more extensive 
modern Tatar historiography of the Khanate. Publications of the well-known Chuvash historian V. D. Dimitriev are included as an example, illustrating the views of other Volga peoples. It is noteworthy that the author, highlighting the widest range of often opposing points of view on the history and nature of the Kazan Khanate's internal structure, does not impose his own assessments on readers allowing them to draw their own conclusions, based on the given material.

In conclusion, I would like to mention again a very substantial historiographic foundation and extensive sources of this monograph, which presents the author as a highly professional historian. We appreciate the excellent language of the book, which indicates to his talent of a publicist. Undoubtedly, this interesting study is Bulat Hamidullin's significant contribution to the research into the history of the Russian Federation. For the present time, of undoubted importance for the harmonious development and strengthening of interethnic and interfaith relations in our multiethnic and multi-religious state is his balanced analysis and assessment of the life and activities of the rulers and population, state and public institutions of the Golden Horde and the Kazan Khanate, made in this book.

\title{
РЕЦЕНЗИЯ НА КНИГУ \\ БУЛАТА ЛИРОНОВИЧА ХАМИДУЛЛИНА \\ «...ОКАЯННАЯ ДЩЕРЬ ЗЛАТОЙ ОРДЫ...»: ОЧЕРКИ И ИСТОРИОГРАФИЧЕСКИЕ ЗАМЕТКИ ПО ИСТОРИИ ЗОЛОТОЙ ОРДЫ И КАЗАНСКОГО ХАНСТВА: МОНОГРАФИЯ. - КАЗАНЬ: ТАТАР. КН. ИЗД-ВО, 2018. - 295 С.
}

\author{
Искандер Аязович Гилязов, \\ Институт татарской энциклопедии и регионоведения АН РТ, \\ Россия, 420111, Казань, ул. Пушкина, д. 56, \\ gilyazov1958@mail.ru.
}

\begin{abstract}
Статья представляет собой рецензию на монографию Б. Л. Хамидуллина, посвященную истории Золотой Орды и Казанского ханства. Выявлена научная новизна данного исследования, кратко охарактеризована его структура, указана актуальность работы.
\end{abstract}

Ключевые слова: Золотая Орда, Казанское ханство, история, историография.

Многовековая история России складывается в том числе из историй населяющих ее народов. Российское многонациональное государство возникло не на пустом месте, его образованию предшествовала история многих государственно-политических формирований, одними из которых являются Золотая Орда и Казанское ханство. Ведь не случайно в 2019 году научная общественность Российской Федерации отмечает 750-летие Золотой Орды. Изучение большого общетюркского и, в частности, татарского наследия и вклада в становление общероссийской государственности имеет огромное значение.

Татарский народ занимает особое положение в истории России как по своей численности (является вторым после русского народа) и территории расселения, так и по вкладу в развитие государственности, культуры, экономики на- шей общей великой страны. Одним из ключевых этапов в этногенезе и развитии татарского народа, его политического устройства, формировании национальной культуры являются 3олотая Орда и постордынские татарские ханства. Также история Золотой Орды и постордынских татарских ханств является значимой частью истории целого ряда народов России: башкирского, крымско-татарского, марийского, мордовского, ногайского, русского, удмуртского, украинского, чувашского и многих других. И неслучайно выдающийся русский историк С. М. Соловьев считал вхождение Казанского ханства в состав России в середине XVI века важнейшим событием отечественной истории, во многом определившим ее дальнейший ход.

В то же время до сих пор Казанское ханство, зачастую по инерции, идущей еще от русского летописания и дореволюционной исто- 
риографии, рассматривается лишь как «враг» («окаянная дщерь Златой орды») Русского государства. С другой стороны, оно у отечественных, в том числе и у собственно татарстанских исследователей, по вниманию к себе пока еще явно уступает, например, Золотой Орде или тюркским империям раннего средневековья, находится в их «густой тени». Поэтому тематика, к которой обращается Булат Лиронович Хамидуллин в своей новой книге, безусловно, более чем актуальна для истории России.

Б. Л. Хамидуллина без преувеличения можно отнести к числу немногочисленных высококлассных специалистов по Казанскому ханству не только в Татарстане, но и в России. Уже более 25 лет он занимается изучением этносоциальной и этнополитической истории средневековых тюрков и татарского Казанского государства. В 2002 году увидела свет его монография «Народы Казанского ханства», ставшая первой почти за 80 лет после работы Михаила Худякова 1923 года «Очерки по истории Казанского ханства» опубликованной книгой, специально посвященной этому государству. Впоследствии им были написаны и изданы еще 5 книг и около 100 научных и научнопопулярных статей по данной тематике. Он является автором посвященных Казанскому ханству статей для Большой российской энциклопедии и раздела о Казанском ханстве в 4-м томе фундаментальной 7-томной «Истории татар с древнейших времен», что говорит о его признанном авторитете в данной области. В результате того что автор является прекрасным публицистом и переводчиком, членом Союза писателей РТ, книга написана прекрасным научно-литературным языком, и ее чтение доставляет удовольствие. Она доступна для разных категорий читателей: как ученых-специалистов, так и просто интересующихся историей.

Структурно книга состоит из трех разделов, объединяющих 19 статей-очерков, а также отдельного приложения - списка публикаций автора по истории Казанского ханства.

Рассказ о собственно Казанском ханстве предваряет раздел, посвященный эпохе Золотой Орды. Он включает 2 больших очерка, в которых скрупулезно рассматриваются все ключевые моменты ее истории и в то же время многие дискуссионные вопросы, в том числе вопросы процесса этнической консолидации 30лотоордынских татар, а также на основе цивилизационного подхода со всех ракурсов показывается уникальный мир золотоордынской эпохи. При этом Б. Л. Хамидуллин привлекает максимально широкий круг источников отечественной и зарубежной историографии.

Хочется подчеркнуть, что автор справедливо считает период Золотой Орды неотъемлемой частью истории России не только как части истории ее тюркских народов, но и всей страны в целом, а также истории многих государств и народов Евразии. По мнению Б. Л. Хамидуллина, ее громадное наследие заключается в том, что Золотая Орда стала «колыбелью» для многих этносов, ныне составляющих значительную часть населения России и сопредельных территорий: татар, башкир, ногайцев, кумыков, узбеков, казахов, а также казачества и др. Именно Золотая Орда впервые на длительное время собрала в едином политическом и экономическом пространстве тюркские, монгольские, финноугорские, восточнославянские, сибирские, кавказские и другие народы Евразии, впоследствии вошедшие в состав России, тем самым дав им первый опыт совместной жизни, сближения культур, жизненного уклада и менталитета.

Золотая Орда напрямую и опосредованно оказала огромное влияние на становление российской государственности. Развиваясь в составе Золотой Орды, Московская Русь вскоре перехватила у нее эстафету собирания земель и народов на просторах Евразии. Россия сохранила многие полезные традиции Орды в системе управления, экономике, культуре. Опыт, полученный в период взаимососуществования с Золотой Ордой, позволил Руси-России превратиться со временем в крупнейшее государство в мире. Все это позволяет автору говорить об исторической преемственности великих евразийских сверхдержав - Золотой Орды, Московского царства, Российской империи, СССР, Российской Федерации, последовательно передававших друг другу миссию «собирания» народов в общих границах.

Второй раздел книги, состоящий из 4 очерков, посвящен богатой истории и в особенности этнополитической ситуации в Казанском ханстве. На основе максимально широкого круга известных на сегодняшний день источников и опубликованных научных работ автор показывает ханство как крупное и экономически развитое государство, структурообразующий элемент региона и всей Центральной Евразии. Автор последовательно, как и в предшествующих своих работах, отстаивает точку зрения и достаточно убедительно доказывает, что Казанское ханство было национальным государством не 
только татар, но и других народов Поволжья и Приуралья, признававших его своей Родиной, осознавших положительные плоды принадлежности к единому общественно-политическому и этнокультурному пространству. Автору удалось выстроить стройную концептуальную схему этнополитической ситуации. В ней, с одной стороны, Казанское ханство рассматривается как целостная этносоциальная общность всех проживавших в нем тюркских и финноугорских народов (особо детально - на примере южных удмуртов), с другой стороны - как «звезда» единого «созвездия» тюрко-татарских государств, возникшего после распада Золотой Орды на основе «единства правящего рода Чингизидов-Джучидов, единства государствообразующего народа с единым языком, единой религией и культурой».

Большую часть книги занимает третий раздел, в котором представлены 14 очерков, посвященных как всей отечественной (российской дореволюционной, советской, постсоветской) историографии Казанского ханства, так и национальной татарской в частности. В них прослеживается ее становление и развитие начиная с летописания XV-XVI веков и заканчивая работами татарских историков начала XXI века, подробно рассмотрены взгляды основоположников и главных исследователей, концептуальные подходы историков и их вклад в изучение истории Казанского ханства. Из данных очерков читатель может узнать и о большом пласте дореволюционной русской историографии, включающем как соответствующие сюжеты в трудах классиков отечественной историографии Н. М. Карамзина, С. М. Соловьева, В. О. Ключевского, Н. И. Костомарова, так и специальные работы П. И. Рычкова, К. Ф. Фукса, Н. К. Баженова, В. В. Вельяминова-Зернова,
Г. И. Перетятковича, С. М. Шпилевского, взгляды на историю Казанского ханства татарских дореволюционных интеллектуалов. Не обойдена вниманием и относительно скудная советская историография, в том числе малоизвестные до недавнего времени широкой публике работы Х. Г. Гимади и Ш. Ф. Мухамедьярова. Отдельный очерк посвящен более обширной современной татарской историографии ханства. Взгляды представителей других поволжских народов показаны на примере публикаций известного чувашского историка В. Д. Димитриева. Примечательно, что автор, освещая самый широкий спектр зачастую противоположных друг другу точек зрения иных ученых на историю и характер внутреннего устройства Казанского ханства, не навязывает читателю своих оценок, предоставляя тому во многом самому делать выводы из прочитанного материала.

В заключение еще раз хочется отметить весьма солидную источниковую и историографическую базу представленной монографии, что характеризует автора как высокопрофессионального историка, и прекрасный слог книги, что свидетельствует о его таланте публициста. Несомненно, данное интересное исследование является значительным вкладом Булата Лироновича Хамидуллина в изучение истории Российской Федерации. Содержащиеся в книге взвешенные анализ и оценка жизнедеятельности правителей и населения, государственных и общественных институтов Золотой Орды и Казанского ханства заслуживают внимание также в контексте вопроса, касающегося гармоничного развития и укрепления межнациональных и межконфессиональных отношений в нашем многоэтничном и поликонфессиональном государстве на современном этапе. 


\section{ТАРИХ ФӘННӘРЕ КАНДИДАТЫ БУЛАТ ЛИРОН УЛЫ ХӘМИДУЛЛИННЫН «...ОКАЯННАЯ ДЩЕРЬ ЗЛАТОЙ ОРДЫ...» (КАЗАН: ТАТАР. КИТ. НӘШР., 2018. - 295 Б.) МОНОГРАФИЯСЕНӘ БӘЯЛӘМӘ}

Искәндәр Аяз улы Гыйләжев, Татарстан Республикасы Фәннәр Академиясенең Татар энциклопедиясе һәм төбәкне өйрәнү институты, Россия, 420111, Казан, Пушкин ур., 56 нче йорт, gilyazov1958@mail.ru.

Мәкалә Б. Л. Хәмидуллинның Алтын Урда һәм Казан ханлыгы тарихына багышланган монографиясенә рецензия. Хезмәттә әлеге тикшеренүнең фәнни яңалыгы ачыклана, аның структурасы кыскача тасвирлана, эшнең актуальлеге күрсәтелә.

Төп төшенчәләр: Алтын Урда, Казан ханлыгы, тарих, историография. 